\title{
The Hierarchy of Oppression, from Authoritarianism to Misogyny: A Study in the Monodrama of Mamdouh 'Udwan
}

\author{
Samar Zahrawi \\ Department of World Languages and Cultures \\ College of Humanities and Social Sciences \\ Sam Houston State University \\ Huntsville, TX, USA. \\ Corresponding Author szahrawi@shsu.edu
}

Received:12/22/2021

Accepted: $1 / 27 / 2022$

Published: $2 / 24 / 2022$

\begin{abstract}
This paper will focus on the drama of the Syrian dramatist and poet Mamdouh 'Udwan (19412004), who has not yet received due critical attention. During his twenty years writing for the stage, 'Udwan resisted oppressive political regimes and was consequently marginalized and impoverished. Due to censorship, his drama does not delineate the free society that he dreams of, nor does it openly censure the sources of corruption. On the contrary, he creates ambiguous male characters who enjoy a measure of dignity and social decorum but simultaneously unravel their toxic masculinity and oppressive nature. On the other hand, women are kept offstage and are victims of either male chauvinism or social hypocrisy. This study will follow the unmasking of male authority and its parallel to political and economic hegemony. The purpose is to critique the values of Arab culture, which customarily cements male privilege. An analytical study of the form and content of 'Udwan's monodramas That's Life (1987), The Garbage Collector (1987), and The Cannibals (1984) will link oppressive social behavior to political autocracy. It suggests that misogyny and oppression of women are consequences of men feeling crushed by dictatorship and corruption.
\end{abstract}

Keywords: Arabic drama, authoritarianism, censorship, corruption, dictatorship, domestic abuse, gynophobia, Mamdouh 'Udwan, madness, misogyny, monodrama, oppression of women, Syrian drama, toxic masculinity, tyranny

Cite as: Zahrawi, S. (2022) The Hierarchy of Oppression, from Authoritarianism to Misogyny: A Study in the Monodrama of Mamdouh 'Udwan. Arab World English Journal for Translation \& Literary Studies 6(1) 20 -29. DOI: http://dx.doi.org/10.24093/awejtls/vol6no1.2 


\section{Introduction}

The Arab World has long suffered from dictatorships and a lack of political freedoms. It also features male superiority over the female. These two domains invite a great deal of activism to introduce much-needed reforms. On the one hand, civil societies need more autonomy to active engagement in political life to reduce corruption everywhere in government and society. On the other hand, women should more visibly participate in civil society's endeavors to attain democracy. This paper analyses the power dynamics in the monodrama of the Syrian playwright and poet Mamdouh 'Udwan (1941-2004) and argues that authoritarianism and the suppression of women in the Arab world are linked. Reform in one domain will bring about improvements in the other.

Psychological research suggested that people scoring high on authoritarianism are inclined to support the maintenance of traditional gender-role identity (Duncan, Peterson \& Winter, 1997, p.46). This study will trace the links between authoritarianism and toxic masculinity in 'Udwan's three monodramas: The Cannibals [Akalat Luhūm al-Bashar] (1984), That's Life [Hal al-Dunya] (1987), and The Garbage Collector [Al-Zabbal] (1987). Despite the absence of women characters, these plays present scathing criticism of the unfair treatment of women and the poor opportunities afforded to them. Avoiding a blatant discussion of the Syrian government, these monodramas also portray pervasive corruption, a decline of values, and authoritarian practices. The avoidance of any direct reference to a certain totalitarian ruler can be ascribed to the heavy-handed censorship and lack of freedom of expression in Syria under the Assad regime (Kahf, 2011, Nice, 2000 and Ziter, 2015). Shying away from offering a panacea, 'Udwan's plays mainly dramatize a sardonic view of the absurdities caused by injustice. These plays with their exasperation- mixed with warm-hearted observations of human behavior, cynical twists, and grim humor- provide ideal material for studying the malaise of the Syrian society under dictatorship. Perhaps it is left for the audience and literary critics to decipher the roots of problems and push towards solutions.

\section{Dramatic Form as a Communicative Tool}

'Udwan stated that his goal in writing literature, rather than a sociological thesis, was to communicate his ideas in an entertaining manner that reaches most people.

I always write to those who would go to sleep if they listened to a lecture in philosophy. I write only to those who share with me the belief that it is still possible to save a human being from the gnaws of another human being ('Udwan,1984, p. 531).

With this humanitarian interest, he uses theatrical techniques to express the central themes of his plays. For example, having a feminist proclivity, 'Udwan often wrote about women's equal rights and dramatized injustices done to women - precariously- in the total absence of female characters. The erasure of the female enables the playwright to portray her extreme disenfranchisement. The very form of the monologue acts as a communicative tool to enact authoritarianism. One character is given the center stage and monopoly over the expressions tools throughout the play. In a letter to the editors detailing his purpose in writing drama with a single actor, 'Udwan said, "I wanted to expose a man's life, so I let him talk at will, and bring out the male, the man, the husband, the father, and the breadwinner" (Jayyusi, 1995, p. 56). In doing so, he delineated the multiple frustrations of the male and his consequent callousness towards the female. The man in That's Life 
is mourning the death of his wife, but the audience discovers that he was cruel to her in the way the world was cruel to him. The retired garbageman in Garbage Collector manifests deep empathy towards the inhabitants of the poverty-ridden alleyway as he learns about their extensive sufferings from their waste. However, he has unwavering resentment towards his daughter-in-law, who aspires for a better lifestyle. The madman in Cannibals loses his mind because of the secret police's excessive cruelty, but he develops a phobia of women eating men alive. Being the single actor, each of the monologists in these three plays acquires the space and power to have full command over the dramatic discourse. In effect, "the monologist represents social authority parallel in kind to both political and economic authority" (Jayyusi, 1995, p. 56). The monologue form helps portray the impact of dictatorship on the individual's psyche. As a defense mechanism against the marginalization of the individual under authoritarianism, the monologist acts as a little dictator on the stage. He has complete control over the narrative, reflecting truth from his own point of view. No multiplicity of voices is allowed. However, being capable of "creating a play with a strikingly cynical twist at the end" (Jayyusi 1995, p. 13), the dramatist keeps unmasking the monologist and allowing him to voluntarily express various facets of himself until the writer's ultimate truth is finally revealed.

\section{The Garbage Collector: Misogyny and Financial Deprivation}

In the long monologue of the Garbage Collector, the male protagonist, Abu-'Adnan, describes the dire poverty of the inhabitants of the alleyway in which he used to serve. He is defensive about his injured dignity and low self-esteem, especially now that he has retired from a life-long job as a garbageman. He believes that his son only wants a relationship with him to use him as a babysitter for his grandson, a job that he miserably failed at in time of emergency. His long monologue is spoken with the background of the continuous cries of an abandoned baby who is later found lifeless in the garbage. This finale accentuates the world's harshness. Learning about people's poverty and illnesses through their discarded waste, he develops deep compassion toward their hardships and feels devastated by the prevalent corruption and apathy.

Looking into the people's waste bins, he knows that Abu-Fahim can no longer afford to buy his son's most needed Asthma medication. Om-Abdulrahman started up the medication for arthritis but could not afford to heat her room or to have her windowpane fixed ('Udwan, 1984a, p. 506). The empty bottles betray the alcoholism of the newspaper columnist. Lamis's waste, which includes contraceptives and objects denoting immoral sexual activities, points to an immoral lifestyle that she has adopted in order to circumvent her abject poverty ('Udwan, 1984, p. 512). He is outraged as the alleyway inhabitants have lost their neighborly solidarity. People now suffer in silence, and "everyone dies alone with one's own pain" ('Udwan, 1984a, p. 512). It is noteworthy that solidarity has cultural affinities with the male gender, which is clear in his comment: "The alleyway used to be an extended family. Any person would take action to safeguard the dignity of the whole alleyway. Aren't there any more men left?" ('Udwan, 1984a, p. 512). He is traumatized because no one helped him save his grandson's life. No car stopped to give him a ride to the emergency room while he was pleading for help with a sick child in hand. The city was a heartless place, "a desert, no son, no friend, no tenderness, no dignity... a desert, nothing around but cement and lights... cars are running with mad speed as if there are no humans around, as if in a desert" ('Udwan, 1984a, p. 526). It is a place that has made him feel worthless: "I am stupid, stupid 
garbage, a waste. I only comprehend garbage where there are no phones, no ambulances, only dirt. He who lives in dirt becomes likewise" ('Udwan, 1984a, p. 528). His lowest point is pictured at the end of the play when he attempts to bury himself under the piles of garbage. However, even in this abys, he can still empathize with the wretched. When he discovers that the child's cries that have just stopped belong to a dead baby cast out in the garbage, his anger with the harsh world is unbridled: "Damn this world which has no place for children, damn this world!" ( Udwan, 1984a, p. 528). He communicates his cynicism towards his own predicaments and those of others with a mixture of human compassion and disgust at the world's injustices.

Despite his empathy for all alley inhabitants, his misogyny towards his socially aspiring daughter-in-law is unmistakable. For him, she is too powerful for her husband, and "her strong will should be broken down by having to breed and nurse lots of babies" ('Udwan, 1987a, p. 521). He views her influenza as a devious ploy to capture her husband's attention. Using cultural and religious misogynistic dictums, he feels righteous about antagonizing her: "God help us from the manipulation of women" ('Udwan, 1987a, p. 520). To him, she is a "serpent" ('Udwan, 1987a, p. 521) who can control her husband and keep him "as obedient as a dog" ('Udwan, 1987a, p.522). Furious at being excluded from her snobbish lifestyle, he takes his life-long frustrations on her. Her attempts at improving her social status are unjustifiable and condemned to him. The oppression the garbage collector has witnessed and suffered throughout his life is projected onto the more vulnerable party in his personal life, the young woman in his family. The misogyny he expresses is just a wish-fulfilling fantasy of superiority

\section{Cannibals: Gynophobia and the Maddening Effect of Tyranny}

In Cannibals, a madman who has just been admitted to solitary confinement in a lunatic asylum hallucinates about 'eating flesh'. He keeps a banner on the wall with the words "They will eat me" ('Udwan, 1984, p. 538) as he is paranoid of the tendency of human beings to eat fellow humans alive. With wry humor, he multiplies on the metaphorical use of the words 'eat', 'devour', and 'blood' in popular expressions, proverbs, and well-known songs to flirt with the ideas of killing, coveting, beating, opportunism, and corruption. The plethora of the ways the term 'eat' is used to connote a vast array of meanings and associations is hilariously witty. For example, the famous song "how to eat you duck" ('Udwan, 1984, p. 539), which signifies sexual appetite, threatens him with real cannibalism. The famous proverb "he knows where the shoulder is eaten" ('Udwan, 1984, p.), which indicates streetwise opportunism, proves to him that humans are innately cannibalistic. The expression "my blood has dried out" ('Udwan, 1984, p.547), which points to excessive nervous tension, is his proof that some people are vampires who can suck the blood out of others. The fixation on such multiple figures of speech range between the comic and the macabre. Having suffered the loss of siblings and friends at the hands of the tyrannical secret police (Mokhabarat), he developed a severe paranoia of being eaten alive and is declared insane. However, there is sense to his hallucinations. Digging into his incoherent sequence of ideas, one can decipher a consistent train of thought that accounts for his madness. Being denied his freedom to mourn and protest the loss of a brother, sister, father, and neighbor due to tyrannical government, he finds that the human race is still capable of primitive brutality, thus his morbid/funny fixation on blood and "eating flesh". 
Everyone eats the other alive. Even the madman's brother and his newly wedded bride devour each other, making loud noises and showing the signs of love bites and hymen blood the following day ('Udwan, 1984, p. 548). Throughout many similar lunatic delusions, some stories present themselves as the apparent reason behind his insanity. For example, his sister Hana's flesh is 'eaten' as she is run over by a car driven by a security officer or his entourage. No one dared to press charges or ever to mention the accident. The family opted to keep quiet to limit the loss. ('Udwan, 1984, p. 551). His brother Samer is 'eaten alive' as he is incarcerated behind the closed doors of the secret police jail. The playwright could not even give them a name. They are "that group that eats people" ('Udwan, 1984, p. 554). The younger brother just disappeared for good. No court case was filed, and the family received no news. His father was "chewed" slowly all his life. He was barely making ends meet like a donkey running after a carrot but never getting it. Having served in a government position for twenty years, the father was forced to resign with no pension, had to resort to plowing fields at his old age, and died of heartbreak. In his job, he had "to be silent, to cast a blind eye on thefts, humiliations, immoralities, family breakdown, abnormalities and murder of girls" ('Udwan, 1984, p.553). The secret police detained his neighbor for several days after humiliating and beating him in public. Having been once a vigorous proud young man, the neighbor came out of jail a completely changed person, utterly quiet and broken. His later mysterious death points to a suicide case because of the disgrace and trauma he experienced after his systematic torture and rape in jail. All these anecdotes of autocracy-related corruption directly caused monologist's madness. He himself was never allowed to express his thought or think freely in the first place. He recollects:

The teacher prevented me from discussing ideas in class. So did my father at home. In college, the professor also prevented me. No one accepts discussion, no discussion. Accept or be quiet, or else... This has been the motto of tyrants since the beginning of time ('Udwan, 1984, p.549).

Therefore, the madman in The Cannibals is paranoid of being eaten alive as the suffering is not limited to his mother, father, sister, brother, and neighbor. "The malaise is in the whole world" ('Udwan, 1984, p. 550). The madman's delusions communicate fear of the monstrosity of human beings under authoritarianism.

In his philosophical hallucinations, he expresses the play's humane theme. He discovers that people are capable of bestiality when they can justify their brutal action, an idea that the playwright studied in length in his non-dramatic book The Bestiality of Human Being (2007). Raging upon his incarceration, he foresees an incurably depraved world that heralds dystopia. The only light at the end of the tunnel is to save the innocent children that have not turned wicked yet. He screams:

Listen, you ferocious beasts. You should change from deep within. In the future, there will be no place for cannibals. The eaten will unite against their eaters... If this rule prevails, all of you will be eaten. You will become like wounded ravenous wolves; each one will devour the other until all of you perish... your only hope is the children. Save the children ('Udwan, 1984, p.569). 
The placard that reads, "They will eat me" is replaced by "They have eaten me" ('Udwan, 1984, p.569). The ending calls for the propagation of humanitarian culture that has been corrupted by tyranny.

Such a humanitarian mission includes freeing women. The madman can now understand the dilemma of women who feel objectified by the male gaze and scrutinized by a judgmental society. He reflects:

God help women! How can a woman walk naturally knowing that the people's gazes are devouring her? All women walk unnaturally. .... I watched my sister walk normally at home. However, when she goes out to the street, she walks as if she is on stage, and just like any actor, she tries to look normal ('Udwan, 1984, pp. 541-2).

In concord with the observations of Nawal Al-Sa dawi, the most outspoken feminist in the Middle East, in her novel Two women in One (1975), he sympathizes with oppressed women. He borrows Sa dawi argument: "They walk in short steps, keeping their legs closed as if they are going to drop something valuable. They always keep to the herd of other women, looking for security from social scrutiny" ('Udwan, 1984, p. 540). However, this humanitarian outlook is impaired by the madman's phobia of women that betrays itself on several occasions. Despite his proclivity for empathy with women, which is demonstrated in his grief over his sister's death and the general dilemma of oppressed women, he fears his sister-in-law and loathes pregnant women's predatory quality. Brides are blood-sucking vampires, especially in bed ('Udwan, 1984, p.547). "They kiss men on the mouth, suck the life out of a man and roar fiercely in orgasm" ('Udwan, 1984, p.548). His sister-in-law, who 'eats' her husband belongs to the chimpanzee kind. She laughs because she does not have a brain and does not worry about it getting eaten ('Udwan, 1984, p.546). To him, all women are partners in one ruthless conspiracy; "either they fill their stomachs with flesh and blood of men or force men to have babies to fill their stomachs with ('Udwan, 1984, p. 546). While the madman's narration of the tragedies caused by the state tyranny is disorganized and muffled, he communicates his phobia of women hyperbolically.

The Cannibals recognizes tyranny as a source of evil that produces injustices, corruption, and degenerate values. However, the monologue does not stop at censuring the abuse of office under a tyrannical system. It, unaccountably, transforms the oppressed into a hater of flesh-eating females. Women are to blame for the world's follies, a tendency that is familiar in theological literature. It seems that shifting the blame to the weaker sex exonerates the male from the responsibility to set the world right.

\section{That's Life: Domestic Abuse and Social Oppression}

The projection of oppression onto women is again dramatized in That's Life (1987). In this play, 'Udwan investigates the development of individuals exposed to injustices, where corruption prevails, where the rich control the poor, where the mighty crush the weak, where the male reflects all of these injustices on the female who is the final recipient of subjugation. The long monologue that constitutes the whole play depicts a man's psychological troubles, a conflict between his legitimate desire to lead a fulfilled, dignified life and his evil side turned sour by grievances over 
pervasive corruption. Despite being crushed, he is turned cruel by the privileges he has as a male. That's Life argues that as men continually suffer such indignities, they do not internalize their inferiority. On the contrary, they compensate for their sense of unworthiness by inflating their grandiose self and becoming absolute dictators at home, treating the wife as a second-class citizen. They even morally justify their abusive behavior by reverting to already established social and religious codes.

A representative of such toxic masculinity in That's Life is Abu- 'Adil. He has just come from his wife's funeral to an empty house. For thirty years, she was a self-denying woman committed to serving him, cooking, cleaning, seldom going out or making any demands until she had a bad heart and died within six months. Abu- 'Adil leaves the mourners at his son's house and insists on staying alone. He had whined and sobbed at her grave until he made all mourners shed tears. "I wept for a life-long companionship, the intimacy of thirty years" ("Udwan 1987 b, p. 60). He feels righteous that he took care of her while she was ill. He even allowed his unmarried neighbor, Samira, of forty years, to take care of her and almost stay with them. At the outset, he appears as a loyal, loving husband who exemplifies social decorum and ethics. However, while pouring out his inner thoughts, his expressions fluctuate between love, bruised dignity, and narcissism, ending in unexpected misogyny. In a gradual process of unmasking the self, he changes from an empathetic character to a repulsive indecent person.

The newly bereaved widower, the "star of the stage" ('Udwan, 1987 b, p. 57), will soon lose the audience's empathy in an ironic turn. He is inconsolable after her death as he feels "crippled" because "Broken bones don't heal so easily when you are old" ('Udwan, 1987 b, p. 57). However, he will only miss her services and the attention he is entitled to as a male, especially since he quotes the holy Qur'an reminding himself that men are superior to women (The Noble Qur'an, 4: 34). While only caring about the show of propriety, he is fixated on male privileges granted to him by religion and society. He is a self-educated, powerless government employee who worked hard to raise his lowly peasantry status. He has fond memories of being treated like a king by a dedicated wife who was intuitive about his daily arrival time and was so caring as to unplug the telephone during his siestas. Despite her tireless servitude to him, he gradually unfolds his arrogance and contempt for her. He never loved her or enjoyed sleeping with her because she was an uneducated inferior peasant who could not match his level of knowledge or sophisticated city lifestyle. As he was unable to express his ideas freely in an autocratic milieu, she became his confidante, not because he trusted she could keep a secret, but because he "was certain that she did not understand it all" ('Udwan, 1987b, p. 61). His anger episodes and recurrent beating of her are his male birthrights. He even righteously justifies this maltreatment of her falsely basing his logic on the Qur'anic verse (4:34):

If you do not accept what I say without arguing, I will beat you. Even the Holy Qur'an has advised us to beat our wives.... I beat you as my birthright. I beat you to give vent to my anger. And where should a man give vent to his anger if not in his own home? ...So I give vent to my anger, I curse you, and I beat you. You must put up with me and be quiet. ('Udwan, 1987b, p .66). 
The more he unfolds his inner thoughts, the more despicable he becomes. He even slows down while calling the doctor on his wife's last night and does not miss the chance of noticing the beautiful body of the doctor's wife underneath the chiffon nightgown. Moreover, during the last six months while his wife was dying, he could not stop himself stalking his neighbor Samira in the shower or while asleep, fetishizing her thighs that are "white as milk" and breasts that are "screaming like hunger" ('Udwan, 1987b, p.455). He even tried to sexually harass her to test if she was the chase kind. Incapable of loving women as equal partners, he mainly wants the gratification of possessing them. Samira is the perfect candidate for marriage after Om- 'Adil's passing, as she has never been married and will not be distracted by any memory of another man. Fantasizing about controlling the body and mind of his future wife is a perfect example of patriarchy as "a state of possession" (Moane, 1999, p. 8)

Underneath the façade of this domineering patriarch is an oppressed male, dwarfed by the hierarchical state. "Abu- 'Adil is an example of an authoritarian Arab man, an angry roaring lion at home, and a petrified rabbit outside the home" (Al-Ra' $\overline{1}, 1987$, p. 429). He is humiliated by pervasive corruption in public life and keeps up false pretenses of dignity, but privately exudes hatred due to his abjectness. Insisting on leaving his sons and staying alone after the funeral, he betrays himself to be a misanthrope, as he hates all the mourners and scorns their consoling calls. He recollects his fawning attitude to "vile and despicable" dignitaries from work that he used to host ('Udwan, 1987b, p. 61). While boasting of his honorable hospitability, he admits to his petty need for them to protect him from a toxic boss. His hypocrisy emanates from his helplessness which is well epitomized in his favorite proverb: "Kiss the hand that you can't bite, and pray for it to break" ('Udwan, 1987b, p. 61). This well-known proverb sums up a culture of pervasive weakness-induced hypocrisy. He does not react when humiliated or cheated by the bullies everywhere at the bread line or the grocery. Instead, he pours his anger onto the wife when she points out that he was tricked into buying spoilt produce. "Stop nagging. I know I have been cheated; I know and keep quiet. Our silence does not mean that we do not know. Rather it means that we can do nothing about it" ('Udwan, 1987b, p. 448). To defend himself, he camouflages his helplessness with a belligerent show of grandiose dignity as he is too good to confront cheaters and low people.

He is a complex case of a victim-offender. His account of the injustices he is exposed to within an overall corrupt authoritarian system casts him in the light of an empathetic protagonist, an anti-hero worthy of compassion. However, the more he peels the onion, his manipulative personality is more evident. His recurrent verbal abuses of his wife are a way of fending off his own self-loathing. He resents his wife because she silently knows his insecurities. "You are afraid of me, so you keep quiet! But I can read your thoughts through your eyes! I can see that you're full of accusations and indictment and that you are silently shouting 'hypocrite'!" ('Udwan, 1987b, p.61). Quoting Hamlet, "A beast would have mourned longer", he brushes off the sense of guilt and gets betrothed to Samira on the very same day of his wife's burial. He reveals a most callous self-entitlement to happiness: "Whoever can't live should die. And if they can't do it, then others should do it for them" ('Udwan, 1987b, p.75). With the multiple layers of intricate lies, he reveals himself to be an utterly abominable selfish person who has been psychologically deformed by the cruelties he has been exposed to. He is prone to inflict the same cruelties on women in his turn. 
Abu- 'Adil's monologue is a form of poetry as it condenses the consequence of oppressive social, religious, and political factors on human identity and values. It dramatizes the pyramid of hierarchical hegemony over the male individual. The forces exerted by the authoritarian government, society, and religion over the male create a cycle of oppression that finds a final recipient in women. Male dictatorship in the family as a response to authoritarianism in the Arab world is best dramatized in the form of monodrama in which a single male is the sole owner of the discourse where no democratic communication is possible. Moreover, the monologue technique is ideal for dramatizing the tragedy of loneliness, demoralization, and disenfranchisement. Moreover, the monologue enables the playwright to delve deep into a man's psyche, one layer at a time. The first layer unfolds grief and loneliness. The Second layer shows his selfishness as he misses services and male privileges. The third layer reveals selective memories reflecting humiliation everywhere in the public domain. The fourth layer links the social and government corruption to the projection of male oppression on women. There is a satirical twist and shift in empathy in which totalitarianism and patriarchy are causally connected in this last layer. The erasure of women from the stage is a deliberate technique to depict the utter disenfranchisement of the female. She is absent from the stage, but her presence is felt as the audience's empathy shifts toward her. Although the play does not offer solutions, it firmly pushes a feminist and democratic ideology.

\title{
Conclusion
}

An analysis of the content and dramatic form of 'Udwan's monodramas That's Life (1987), The Garbage Collector (1987), and The Cannibals (1984) suggests that women are oppressed as a consequence of men being crushed by extraneous forces in public life. To write for the stage, 'Udwan needed to circumvent the state's censorship of any criticism of the present government. Instead of delineating the free society that he dreams of, he delves deep into portraying man's compensatory process while receiving public oppression and transferring it to the private sphere. His ambivalent male characters turn out to be dignity-seeking empathetic characters and, at the same time, toxically oppressive males. On the other hand, women are completely disenfranchised as they have neither a stage presence nor a voice. The gradual unmasking of the male in these three monodramas is a creative dramatic feat as it links the atomization of the male within a corrupt authoritarian system to the individual's need to regain control by exercising the same cruelty on others. The injustices practiced by the domineering male over the submissive female indirectly comment on Arab socio-political reality, which features dictatorships and a hierarchical sequence of dominations, submissions, and subjugation. As dictatorship and corruption oppress the individuals, the society, in turn, replicates the same cycle of oppression within its components, with the female at the bottom of the hierarchical pyramid. Men who are active in public life assume the role of the oppressor over silent marginalized women. So, freeing women requires freeing the entire civil society.

\begin{abstract}
About the Author
Samar Zahrawi received her Ph.D. from the University of Leeds, the U.K. in Modern Drama in 1992. She taught modern drama at Al-Baath University, Syria, and King Saud University, KSA. Currently, she is an Associate Professor of Middle Eastern Studies at Sam Houston State University, Texas, USA. Having a background in English and comparative drama, her current research interest is Arabic drama, Arabic culture, and translation studies. ORCid https://orcid.org/0000-0002-6897-523X
\end{abstract}

Arab World English Journal for Translation \& Literary Studies 
AWEJ for Translation \& Literary Studies Volume, 6 Number 1. February 2022

The Hierarchy of Oppression: The Monodrama of Mamdouh 'Udwan

Zahrawi

\section{References}

Al-Ra' $\overline{1}$, A. (1987). Introduction to Hal al-dunya, a mature monodrama. Al-Musawar Magazine. Issue (Dec 11th, 1987). Cairo: Dar al-Hilal. Also reprinted in Mamdouh 'Udwan. (2006). The dramatic works [al-a'mal al-masrahiyya] (Vol. 2, pp. 427-433). Syria: Mamdouh 'Udwan publishing house.

Duncan L.E., Peterson B.E., \& Winter D.G. (1997). Authoritarianism and gender roles: Toward a psychological analysis of hegemonic relationships. Personality and Social Psychology Bulletin. 23(1):41-49. doi:10.1177/0146167297231005

Jayyusi, S. K., \& Roger, A. (Eds). (1995). Modern Arabic drama: An anthology. Bloomington and Indianapolis: Indiana University Press.

Kahf, M. (Spring 2001). The silences of contemporary Syrian literature. World Literature Today, 75(2), 224-236. Also accessed on Sep 10 ${ }^{\text {th }}, 2014$ from Full-text Online Library, 1-18 http://www.thefreelibrary.com/The+silence +of +contemporary+Syrian+literature.a080500168.

Moane, G. (1999). Gender and colonialism: A psychological analysis of oppression and liberation. New York: Palgrave Macmillan. Accessed on Oct 10 ${ }^{\text {th }}, 2020$ from https://books.google.com/books?hl=en\&lr=\&id=cVWCDAAAQBAJ\&oi=fnd\&pg=PR2 $\& \mathrm{dq}=$ psychological+impact+of+oppression\&ots=3MH6bvXQQM\&sig=dIGNcKK3504r $3 \mathrm{k} 7 \mathrm{qmH}$ rroS5JsHM\#v=onepage $\& \mathrm{q}=$ psychological $\% 20 \mathrm{impact} \% 20 \mathrm{of} \% 20 \mathrm{oppression} \& \mathrm{f}=\mathrm{f}$ alse.

Nice, P. (Spring 2000). Finding the right language: A conversation with Syrian filmmaker Usama Muhammad. Al-Jadid: A Review \& Record of Arab Culture \& Arts, 6 (31), 10-25. Accessed Sept25th, 2005 from http://www.aljadid.com/content/finding-right-languageconversation-syrian-filmmaker-usama-muhammad.

The Noble Qur'an. (n.d.). https://quran.com/4.

Sa'dawi, N. (1975). Two women in One [Imra' atan fi Wahida]. Cairo: Dar al-Adāb.

'Udwan, M. (1984). The cannibals [Akalat luhūm al-bashar]. In Mamdouh 'Udwan. (2006). The dramatic works [al-a 'mal al-masrahiyya] (Vol. 2, pp. 529-569). Syria: Mamdouh 'Udwan publishing house.

'Udwan, M. (1987) (a). The garbage collector [Al-zabbal]. In Mamdouh 'Udwan. (2006). The dramatic works [al-a 'mal al-masrahiyya] (Vol. 2, pp. 503-528). Syria: Mamdouh 'Udwan publishing house.

'Udwan, M. (1987) (b). That's life [Hal al-dunya]. In Mamdouh 'Udwan. (2006). The dramatic works [al-a'mal al-masrahiyya] (Vol. 2, pp. 425-466). Syria: Mamdouh 'Udwan publishing house.

'Udwan, M. (2007). The bestiality of the human being [Haywanat Al-Insan]. Syria: Mamdouh 'Udwan publishing house.

Ziter, E. (2015). Political performance in Syria: From the Six-Day War to the Syrian uprising. UK. Palgrave Macmillan.

Arab World English Journal for Translation \& Literary Studies 